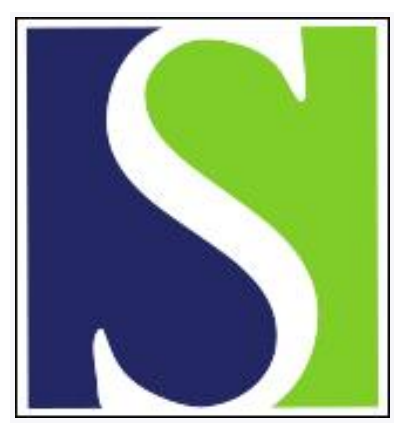

Scand J Work Environ Health 1985;11(1):27-32

https://doi.org/10.5271/sjweh.2257

Issue date: Feb 1985

Respiratory symptoms and pulmonary function among welders working with aluminum, stainless steel and railroad tracks.

by Sjogren B, Ulfvarson U

This article in PubMed: www.ncbi.nlm.nih.gov/pubmed/3992218

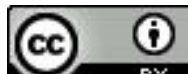




\title{
Respiratory symptoms and pulmonary function among welders working with aluminum, stainless steel and railroad tracks
}

\author{
by Bengt Sjögren, MD, ${ }^{1}$ Ulf Ulfvarson, DTech ${ }^{2}$
}

\begin{abstract}
SJÖGREN B, ULFVARSON U. Respiratory symptoms and pulmonary function among welders working with aluminum, stainless steel and railroad tracks. Scand J Work Environ Health 11 (1985) 27-32. Sixty-four aluminum welders, 46 stainless steel welders, and 149 railroad track welders were investigated regarding respiratory symptoms and pulmonary function (forced vital capacity and forced expiratory volume in $1 \mathrm{~s}$ ). Referents consisted of nonwelding industrial workers and raiload workers. All groups of welders showed a higher frequency of chronic bronchitis symptoms than their respective referents. Respiratory symptoms were related to ozone concentrations in welders working with aluminum. In stainless steel and railroad track welders respiratory symptoms were related to chromium exposure rather than to total particle exposure. The pulmonary function was not affected in any of the welding groups studied.
\end{abstract}

Key terms: chromium, chronic bronchitis.

Welding is a process of fusing metals together by melting. Electric-arc welding uses techniques to protect the melting metal from the oxidizing power of the air. In metal arc welding the melted metal is protected by material in the coating of the electrode, and in gas-shielded welding an inert gas acts as protection. Two different methods of gas-shielded welding are used. Metal inert-gas (MIG) welding uses a consumable electrode, and in tungsten inert-gas (TIG) welding a nonconsumable electrode of wolfram is used.

Welding generates particles and gases which are characteristic for the method used and the material welded. Gas-shielded welding of aluminum produces ultraviolet radiation, which causes oxygen in the air to form ozone (7). Recently a case of pulmonary fibrosis was reported for a worker who had welded aluminum for 17 years, mainly in confined spaces (28). Manual metal arc welding with coated electrodes on stainless steel generates particles of easily soluble hexavalent chromium $(19,25,27)$. The major component of welding fumes from low-alloy steel is iron oxide (23).

The purpose of this study was to investigate respiratory symptoms in relation to concentrations of air contaminants and pulmonary function in different groups of welders as part of a comprehensive study of Swedish welders.

\footnotetext{
1 Research Department, National Board of Occupational Safety and Health, S-171 84 Solna, Sweden.
}

Reprint requests to: Dr B Sjögren, Section of Occupational Medicine, Research Department, National Board of Occupational Safety and Health, S-171 84 Solna, Sweden.

\section{Subjects}

The three different exposed populations were identified in two different ways.

Enterprises consuming welding material were traced in a Register of Enterprises held by the National Bureau of Statistics. Representatives from companies with some welding material consumption were interviewed about the number of welders, the material welded, and the method used, as well as the welding intensity for each welder. At the time of the study about 200 welders in the country worked mainly on aluminum with gas-shielded welding, and about 400 welders worked mainly on stainless steel with coated electrodes (11). Aluminum and stainless steel welders were included in the investigation if they had worked for at least one year with the method being studied and at least $3.5 \mathrm{~h}$ each workday and were present on the days of the examination. In the interview many welders stated less welding time than that estimated by the representatives of the companies. The welders worked in a geographic region extending from $600 \mathrm{~km}$ south to $300 \mathrm{~km}$ north of Stockholm.

One group of 64 welders working with gas-shielded welding (both MIG and TIG) on aluminum, agreed to participate in the study and none refused. The median exposure time of this group was 5 (range 1-24) years.

All 46 welders who worked with coated electrodes on stainless steel and who fulfilled the entrance criteria agreed to participate in the study. Their median exposure time was 15 (range $1-39$ ) years.

At the time of the study 215 persons were welding railroad tracks for the Swedish State Railways. Welders working in remote areas of the country were excluded from the study for practical reasons. No 
specific restrictions as to welding time per day were applied to this group. One hundred and forty-nine welders accepted participation and none refused. The welding work consisted mainly of joining rails by mold welding and overlay welding of worn or damaged rails. Basic electrodes were used in both operations. The electrode used for overlay welding contained $3.2 \%$ chromium. The median exposure time of these welders was 18 (range 5-41) years.

An aged-matched (within four years) referent was chosen for each aluminum and stainless steel welder. These referents were nonwelding industrial workers chosen from the same company or from the geographically nearest company. If possible the referents were also matched for smoking habits.

Referents for the railroad track welders were nonwelding railroad workers from about the same geographic areas as the welders. The number of

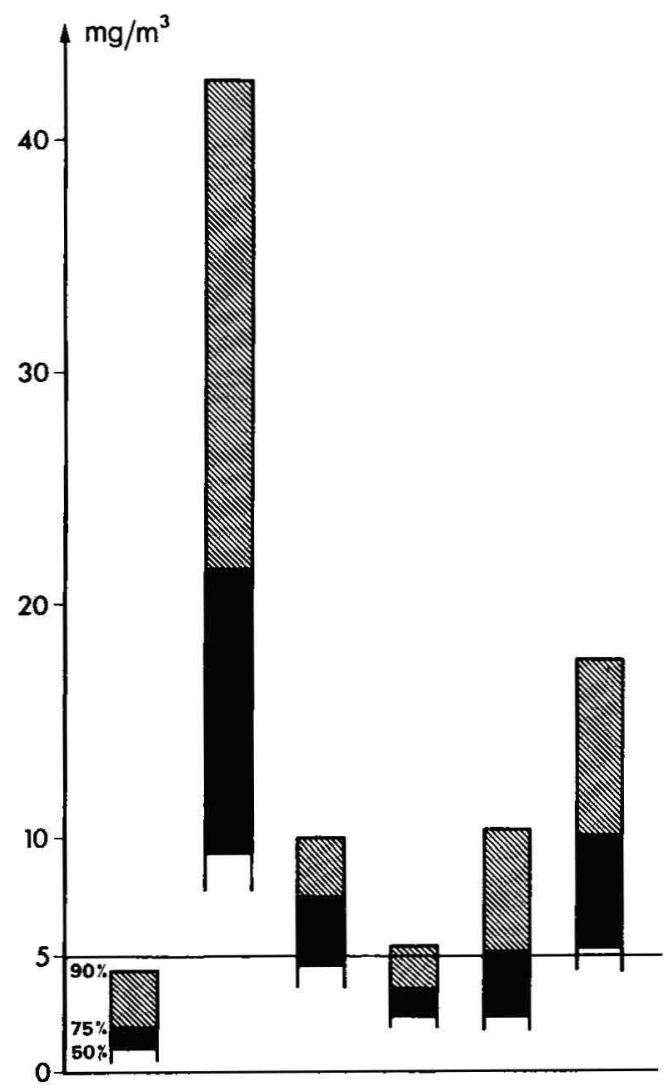

\section{A $B$ B C $\quad D \quad E$ E}

Figure 1. Distribution of total particle concentration in different welding operations according to Ulfvarson (26). The percentages marked in the lower left-hand corner of the figure show the percentage of measurements represented by the column area in question. (The current occupational exposure limit for respirable particles is $5 \mathrm{mg} / \mathrm{m}^{3}$.) (A = tungsten inert-gas welding of aluminum, $\mathrm{B}=$ metal inert-gas welding of aluminum, $\mathrm{C}=$ coated electrodes on stainless steel, $D=$ tungsten inert-gas welding of stainless steel, $E=$ coated electrodes in the overlaying of rails, F = coated electrodes in rail splicing). referents was 70 , and they were neither individually matched for age nor for smoking habits.

All the welders and referents were males.

\section{Methods}

The welding fume samples were collected on cellulose ester membrane filters (Millipore filter AAWP, diameter $37 \mathrm{~mm}$, mean pore size $0.8 \mu \mathrm{m}$ ) with personal sampling pumps (MSA monitaire sampler pump, model G) with a calibrated flow. The filters were placed inside the welding helmet. Total particle welding fume amounts were measured gravimetrically. The sampling period was at least $4 \mathrm{~h}$, and timeweighted average concentrations for the sampling period were calculated.

Total chromium amounts were analyzed with a particle-induced X-ray emission (PIXE) technique at the Department of Nuclear Physics, Institute of Technology, Lund. The detection limit was $0.1 \mu \mathrm{g} /$ $\mathrm{m}^{3}(26)$, and the coefficient of variation was $10 \%$ (14).

Ozone was measured by a chemiluminiscence instrument inside the welding helmet. This instrument is practically specific for ozone, and the detection limit is about $0.001 \mathrm{ppm}$ (26). These measurements were performed during at least two 15 -min periods.

Ulfvarson (26) has thoroughly described all the methods used for the assessment of particles and gases in these studies, and all measurements were aimed to represent normal work conditions.

All the participants were interviewed in a standardized way. A modification of the British Medical Research Council's questionnaire on respiratory symptoms was used. Chronic bronchitis was defined as daily cough and production of phlegm for as much as three months each year. This definition is very close to that given by the World Health Organization (30).

Forced vital capacity (FVC) and forced expiratory volume in $1 \mathrm{~s}\left(\mathrm{FEV}_{1.0}\right)$ were registered at least three times for each person with a vitalograph. The tests were performed with the subjects in the standing position and without a noseclip. The best value for each variable was used in the analysis, and all volumes were corrected to body temperature and pressure saturated with water vapor (BTPS). Regression equations were calculated in which age and height were independent variables and FVC and $\mathrm{FEV}_{1.0}$ were dependent variables.

Two vitalographs were used during the study. At the end of the data collection one spirometer showed plus 0.11 at the 5-1 calibration and the other minus $0.1 \mathrm{l}$ at the same volume.

Nonsmokers were defined as subjects who had never smoked or who had quit smoking more than two years ago. Subjects who stopped smoking less than two years ago were excluded. 
Table 1. Reported chronic bronchitis among the subgroups of welders and their referents. Welders with exposure of less than 2 years were excluded.

\begin{tabular}{lcccccc}
\hline \multirow{2}{*}{ Type of welding } & \multicolumn{2}{c}{ Welders } & & \multicolumn{2}{c}{ Referents } & $\begin{array}{c}\text { Crude } \\
\text { risk } \\
\text { ratio }\end{array}$ \\
\cline { 2 - 3 } & $\begin{array}{c}\text { Total } \\
\text { number }\end{array}$ & $\begin{array}{c}\text { Number with } \\
\text { bronchitis }\end{array}$ & & $\begin{array}{c}\text { Total } \\
\text { number }\end{array}$ & $\begin{array}{c}\text { Number with } \\
\text { bronchitis }\end{array}$ & \\
$\begin{array}{l}\text { Gas-shielded welding } \\
\text { on aluminum }\end{array}$ & 59 & 4 & 64 & 2 & 2.2 \\
$\begin{array}{l}\text { Coated electrodes on } \\
\text { stainless steel }\end{array}$ & 44 & 4 & 46 & 2 & 2.1 \\
Railroad track welding & 149 & 7 & 70 & 1 & 3.3 \\
\hline
\end{tabular}

The differences in the frequencies were tested by the chi-square test, and the differences in the means were tested by Student's t-test. The Mantel-Haenszel test was used for the analysis of stratification (20). The p-values refer to two-tailed tests. Statistical significance means that $\mathrm{p}<0.05$.

\section{Exposure}

Electric-arc welding generates fume in which the majority of the particles are smaller than $1 \mu \mathrm{m}$ and thus respirable $(2,26)$. The distribution of the total particle concentrations for different welding operations without local exhaust ventilation is shown in figure 1 .

The current Swedish occupational exposure limit for hexavalent chromium is $20 \mu \mathrm{g} / \mathrm{m}^{3}$. More than $80 \%$ of the chromium concentrations exceeded that value when stainless steel was welded with coated electrodes.

The current Swedish 8-h occupational exposure limit for ozone is $0.1 \mathrm{ppm}$. Almost $50 \%$ of the ozone concentrations exceeded that limit when MIG welding was performed on aluminum. The concentrations of oxides of nitrogen were typically below $5 \mathrm{ppm}$, regardless of the welding method.

The exposure conditions have been extensively analyzed and published by Ulfvarson (26).

\section{Results}

\section{Chronic bronchitis}

All the groups of welders reported higher frequencies of chronic bronchitis than their respective referents, but the differences were not statistically significant (table 1).

As smoking is strongly associated with chronic bronchitis, a stratification due to smoking was made (table 2). All the welders were included, as the number of welders with chronic bronchitis was very small in each subgroup. This analysis showed smoking to be a stronger determinant for chronic bronchitis than welding fume exposure.
Table 2. Reported chronic bronchitis among all the welders and their referents divided into smokers and nonsmokers. Welders with exposure of less than 2 years were excluded. ${ }^{a}$

\begin{tabular}{lccccc}
\hline & \multicolumn{2}{c}{ Welders } & & \multicolumn{2}{c}{ Referents } \\
\cline { 2 - 3 } \cline { 5 - 6 } & $\begin{array}{c}\text { Total } \\
\text { number }\end{array}$ & $\begin{array}{c}\text { Number } \\
\text { with } \\
\text { bronchitis }\end{array}$ & & $\begin{array}{c}\text { Total } \\
\text { number }\end{array}$ & $\begin{array}{c}\text { Number } \\
\text { with } \\
\text { bronchitis }\end{array}$ \\
\cline { 2 - 5 } Smokers & 119 & 12 & & 82 & 5 \\
Nonsmokers & 128 & 3 & & 94 & 0 \\
\hline
\end{tabular}

a Crude risk ratio due to welding: $2.14(p=0.12)$; risk ratio after stratification for smoking: $2.08(p=0.13)$. Crude risk ratio due to smoking: $6.26(p<0.001)$; risk ratio after stratification for welding: $6.15(p<0.001)$.

\section{Respiratory symptoms related to welding}

All three groups of welders had significantly more respiratory symptoms (eg, cough, phlegm, or a sense of irritation) in connection with work than their respective reference group. In general these symptoms were of shorter duration than the symptoms included in the definition of chronic bronchitis.

Welders working with gas-shielded welding on aluminum had more respiratory symptoms at higher ozone concentrations than at lower concentrations (figure 2). A comparison between exposure category I and category II gave a p-value of 0.03 .

Respiratory symptoms were more common at higher than at lower chromium concentrations among stainless steel, as well as among railroad track, welders (figures $3 \& 4$ ), but this tendency was not statistically significant.

Respiratory symptoms did not seem to show any relationship with the total particle concentrations of the three groups of welders.

\section{Pulmonary function}

As FVC and $\mathrm{FEV}_{1.0}$ vary with age and height, all these variables are presented (table 3 ). There were no differences regarding $\mathrm{FVC}$ or $\mathrm{FEV}_{1.0}$ between the three groups of welders and their respective reference groups. Neither did the subjects with long exposure periods have decreased pulmonary function variables. 
OZONE

$\%$ with respiratory symptoms

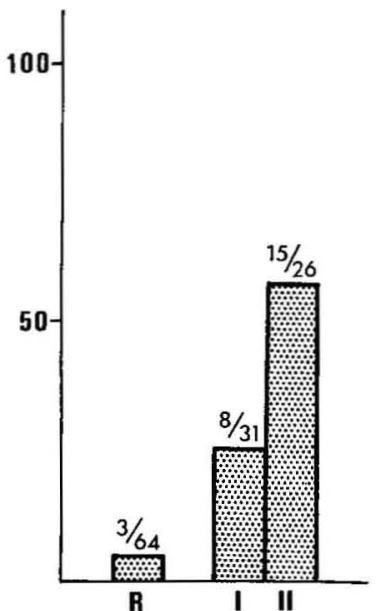

$\mathrm{I}=<0.05 \mathrm{ppm}$

II $=\geq 0.05 \mathrm{ppm}$
PARTICLES

$\%$ with respiratory symptoms

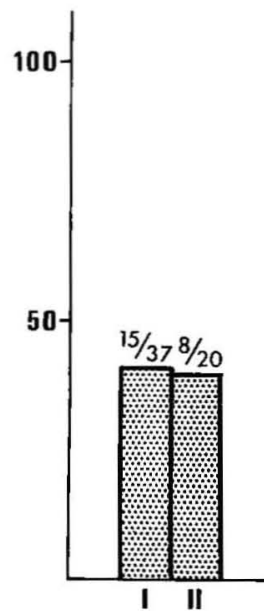

$\mathrm{I}=<5.0 \mathrm{mg} / \mathrm{m}^{3}$

II $=\geq 5.0 \mathrm{mg} / \mathrm{m}^{3}$

Figure 2. Respiratory symptoms of the referents $(R)$ and the groups of welders (working with gas-shielded welding of aluminum) with different levels of exposure to ozone and particles.

\section{CHROMIUM}

$\%$ with respiratory

symptoms

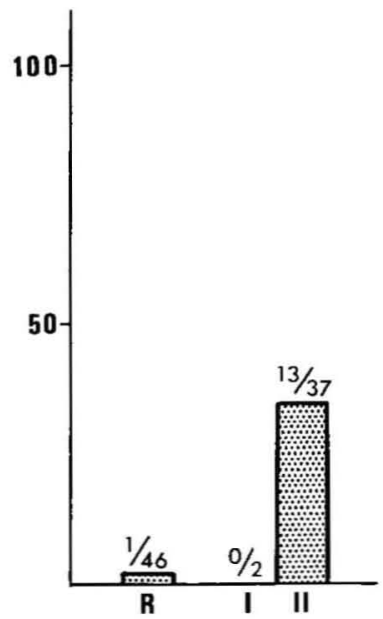

$\mathrm{I}=<20 \mu \mathrm{g} / \mathrm{m}^{3}$

$\mathrm{II}=\geq 20 \mu \mathrm{g} / \mathrm{m}^{3}$

\section{PARTICLES}

$\%$ with respiratory symptoms

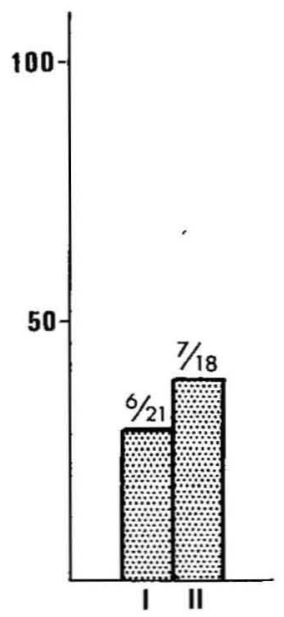

$\mathrm{I}=<5.0 \mathrm{mg} / \mathrm{m}^{3}$

II $=\geq 5.0 \mathrm{mg} / \mathrm{m}^{3}$

Figure 3. Respiratory symptoms of the referents $(R)$ and the groups of welders (working with coated electrodes on stainless steel) with different levels of exposure to chromium and particles.

\section{Discussion}

\section{Chronic bronchitis}

Published reports on welders have explicitly or implicitly concerned electric-arc welding on low-alloyed steel, and they have shown an increased frequency of chronic bronchitis with risk ratios varying between 1.2 and $3.1(1,3,4,5,8,22)$. This study also showed somewhat increased frequencies of chronic bronchitis in all the subgroups of welders, close to the previously found risk ratios.

Smoking affected the frequency of chronic bronchitis more than welding. The risk ratio was within the earlier-reported range of $2-14(10,17$, 21, 29).

Stainless steel welding with coated electrodes has previously been associated with asthma (16). The present study did not reveal obstructive disease among the exposed subjects, a finding which could be explained by selection through job exchange for welders with severe respiratory disorders.

\section{Respiratory symptoms related to welding}

The present study showed ozone rather than aluminum particles to be responsible for the respiratory symptoms among the aluminum welders, this finding is in accordance with the results of an experimental study (9) in which $0.35 \mathrm{ppm}$ of ozone, but not

\section{CHROMIUM}

$\%$ with respiratory

symptoms

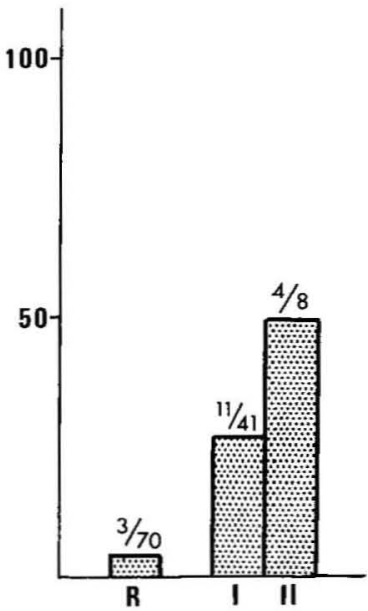

$\begin{aligned} \mathrm{I} & =<20 \mu \mathrm{g} / \mathrm{m}^{3} \\ \mathrm{II} & =\geq 20 \mu \mathrm{g}, \mathrm{m}^{3}\end{aligned}$

\section{PARTICLES}

$\%$ with respiratory symptoms

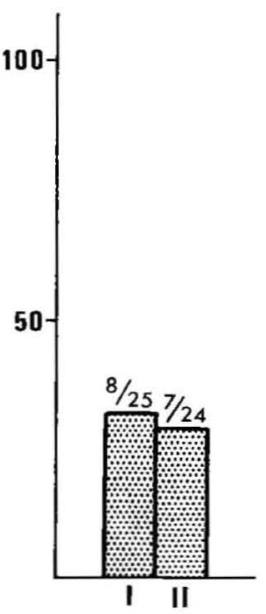

$\mathrm{I}=<5.0 \mathrm{mg} / \mathrm{m}^{3}$

II $=\geq 5.0 \mathrm{mg} / \mathrm{m}^{3}$
Figure 4. Respiratory symptoms of the referents $(R)$ and the groups of railroad track welders with different levels of exposure to chromium and particles. 
Table 3. Mean values for the age, height, forced vital capacity, and forced expiratory volume in $1 \mathrm{~s}$ of aluminum, stainless steel, and railroad track welders and their respective referents.

\begin{tabular}{|c|c|c|c|c|c|}
\hline Group & Number & $\begin{array}{c}\text { Age } \\
\text { (years) }\end{array}$ & $\begin{array}{l}\text { Height } \\
(\mathrm{cm})\end{array}$ & $\begin{array}{l}\text { Forced vital } \\
\text { capacity } \\
\text { (I) }\end{array}$ & $\begin{array}{l}\text { Forced expiratory } \\
\text { volume in } 1 \mathrm{~s} \\
(1 / \mathrm{s})\end{array}$ \\
\hline \multicolumn{6}{|l|}{ All welders } \\
\hline $\begin{array}{l}\text { Aluminum welders } \\
\text { Referents }\end{array}$ & $\begin{array}{l}64 \\
64\end{array}$ & $\begin{array}{l}37.3 \\
37.3\end{array}$ & $\begin{array}{l}176.7 \\
175.1\end{array}$ & $\begin{array}{l}5.36 \\
5.13\end{array}$ & $\begin{array}{l}4.34 \\
4.18\end{array}$ \\
\hline $\begin{array}{l}\text { Stainless steel welders } \\
\text { Referents }\end{array}$ & $\begin{array}{l}46 \\
46\end{array}$ & $\begin{array}{l}45.7 \\
45.7\end{array}$ & $\begin{array}{l}175.0 \\
174.9\end{array}$ & $\begin{array}{l}5.00 \\
4.98\end{array}$ & $\begin{array}{l}3.97 \\
3.96\end{array}$ \\
\hline $\begin{array}{l}\text { Railroad track welders } \\
\text { Referents }\end{array}$ & $\begin{array}{r}148 \\
70\end{array}$ & $\begin{array}{l}46.6 \\
46.8\end{array}$ & $\begin{array}{l}175.7 \\
175.2\end{array}$ & $\begin{array}{l}5.12 \\
5.17\end{array}$ & $\begin{array}{l}4.07 \\
4.09\end{array}$ \\
\hline \multicolumn{6}{|l|}{ Nonsmokers } \\
\hline $\begin{array}{l}\text { Aluminum welders } \\
\text { Referents }\end{array}$ & $\begin{array}{l}28 \\
31\end{array}$ & $\begin{array}{l}38.9 \\
39.2\end{array}$ & $\begin{array}{l}175.9 \\
174.9\end{array}$ & $\begin{array}{l}5.38 \\
5.12\end{array}$ & $\begin{array}{l}4.37 \\
4.23\end{array}$ \\
\hline $\begin{array}{l}\text { Stainless steel welders } \\
\text { Referents }\end{array}$ & $\begin{array}{l}21 \\
25\end{array}$ & $\begin{array}{l}46.2 \\
47.1\end{array}$ & $\begin{array}{l}175.3 \\
174.6\end{array}$ & $\begin{array}{l}4.97 \\
4.96\end{array}$ & $\begin{array}{l}3.97 \\
4.01\end{array}$ \\
\hline $\begin{array}{l}\text { Railroad track welders } \\
\text { Referents }\end{array}$ & $\begin{array}{l}82 \\
38\end{array}$ & $\begin{array}{l}46.3 \\
47.6\end{array}$ & $\begin{array}{l}175.4 \\
174.6\end{array}$ & $\begin{array}{l}5.15 \\
5.26\end{array}$ & $\begin{array}{l}4.17 \\
4.23\end{array}$ \\
\hline \multicolumn{6}{|l|}{ Smokers } \\
\hline $\begin{array}{l}\text { Aluminum welders } \\
\text { Referents }\end{array}$ & $\begin{array}{l}34 \\
33\end{array}$ & $\begin{array}{l}35.7 \\
35.5\end{array}$ & $\begin{array}{l}177.5 \\
175.3\end{array}$ & $\begin{array}{l}5.33 \\
5.14\end{array}$ & $\begin{array}{l}4.34 \\
4.13\end{array}$ \\
\hline $\begin{array}{l}\text { Stainless steel welders } \\
\text { Referents }\end{array}$ & $\begin{array}{l}23 \\
20\end{array}$ & $\begin{array}{l}45.6 \\
43.5\end{array}$ & $\begin{array}{l}175.0 \\
175.0\end{array}$ & $\begin{array}{l}5.08 \\
5.09\end{array}$ & $\begin{array}{l}4.00 \\
4.00\end{array}$ \\
\hline $\begin{array}{l}\text { Railroad track welders } \\
\text { Referents }\end{array}$ & $\begin{array}{l}64 \\
29\end{array}$ & $\begin{array}{l}47.1 \\
46.4\end{array}$ & $\begin{array}{l}176.3 \\
176.0\end{array}$ & $\begin{array}{l}5.09 \\
5.01\end{array}$ & $\begin{array}{l}3.95 \\
3.87\end{array}$ \\
\hline
\end{tabular}

$0.20 \mathrm{ppm}$, was associated with respiratory symptoms.

In a previous cross-sectional study of stainless steel and mild steel welders both groups had about the same frequency of respiratory symptoms (15); this finding agrees with the results of the present study.

For the stainless steel welders, as well as for the railroad track welders, respiratory symptoms seemed to be more correlated with chromium exposure than with total particle exposure. Most of the chromium is in a hexavalent state $(19,25,27)$, and such compounds are known to be highly irritative (18).

\section{Pulmonary function}

As mentioned in the Methods section two vitalographs were used. One showed plus 0.11 and the other minus 0.11 at $5 \mathrm{l}$. Each vitalograph was used to investigate an equal number of exposed welders, as well as referents in a particular workshop, ie, an equal proportion of welders and referents were investigated with the same spirometer. Thus the internal validity was adequate for the study. Furthermore, the regression equations, in which FVC and $\mathrm{FEV}_{1.0}$ were calculated from height and age, were similar to previously reported equations (6).

In recent case reports pulmonary fibrosis and desquamative interstitial pneumonia have been discovered in two aluminum welders $(12,28)$. These cross-sectional data do not support any deterioration due to long-term exposure. The inherent selection weakness of a cross-sectional study must however be borne in mind.

The present study supports the findings of one published study showing no effect on pulmonary function in stainless steel welders in a comparison with reference values (15).

The railroad track welders in this study did not exhibit any impairment of pulmonary function. Obstructive changes have been observed previously among shipyard welders $(1,13)$. These differences concerning pulmonary function might be explained by the fact that shipyard welders often work in semiconfined or confined spaces, contrary to railroad track welders, and therefore are exposed to higher concentrations of air contaminants. In railroad track welding $25-50 \%$ of the measured total particle concentrations inside the welding helmet exceeded $5 \mathrm{mg} / \mathrm{m}^{3}$ (figure 1), and in Danish shipyards $50 \%$ of the measurements in confined spaces were above $7 \mathrm{mg} / \mathrm{m}^{3}$ (24). However, the results from our study are in accordance with the spirometric results from welders working in engineering shops (3).

\section{Acknowledgments}

We wish to thank Ms M Håkansson, Dr H Malmgren, Mr J Persson, and Ms E Randma for their technical assistance, Prof $\AA$ Swensson for his planning advice, and Prof $\mathrm{C}$ Hogstedt for his comments on the manuscript.

This work has been supported by a grant from the Swedish Work Environment Fund.

\section{References}

1. Akbarkhanzadeh F. Long-term effects of welding fumes upon respiratory symptoms and pulmonary 
function. J Occup Med 22 (1980) 337-341.

2. American Welding Society. The welding environment. Miami, FL 1973. 169 p.

3. Antti-Poika M, Hassi J, Pyy L. Respiratory diseases in arc welders. Int Arch Occup Environ Health 40 (1977) 225-230.

4. Axelson O. Svetsarbronkit. Läkartidningen 71 (1974) 479-482. (English abstract).

5. Barhad B, Teculescu D, Craciun O. Respiratory symptoms, chronic bronchitis and ventilatory function in shipyard welders. Int Arch Occup Environ Health 36 (1975) 137-150.

6. Berglund E, Birath G, Bjure J, Grimby G, Kjellmer I, Sandqvist L, Söderholm B. Spirometric studies in normal subjects: Forced expirograms in subjects between 7 and 70 years of age. Acta Med Scand 173 (1963): 2, 185-192.

7. Challen PJR, Hickish DE, Bedford J. An investigation of some health hazards in an inert-gas tungsten-arc welding shop. Br J Ind Med 15 (1958) 276-282.

8. Fogh A, Frost J, Georg J. Respiratory symptoms and pulmonary function in welders. Ann Occup Hyg 12 (1969) $213-218$.

9. Folinsbee LJ, Bedi JF, Horvath SM. Respiratory responses in humans repeatedly exposed to low concentrations of ozone. Am Rev Respir Dis 121 (1980) $431-439$.

10. Haenszel W, Hougen A. Prevalence of respiratory symptoms in Norway. J Chronic Dis 25 (1972) 519-544

11. Hallne U, Erlandsson A. Förekomst av svetsning i aluminium och rostfritt stål samt lödning med silverlod inom svensk tillverkningsindustri [The occurrence of welding in aluminum and stainless steel in Swedish manufacturing industry]. National Board of Occupational Safety and Health, Solna 1977. (Undersökningsrapport 1977: 6)

12. Herbert A, Sterling G, Abraham J, Corrin B. Desquamative interstitial pneumonia in an aluminum welder. Hum Pathol 13 (1982) 694-699.

13. Hunnicutt TN Jr, Cracovaner DJ, Myles JT. Spirometric measurements in welders. Arch Environ Health 8 (1964) $661-669$.

14. Johansson SAE, Johansson TB. Analytical applications of particle induced X-ray emission. Nucl Instrum Methods 137 (1976) 473-516.

15. Kalliomäki P-L, Kalliomäki K, Korhonen O, Nordman H, Rahkonen E, Vaaranen V. Respiratory status of stainless steel and mild steel welders. Scand J Work Environ Health 8 (1982): suppl 1, 117-121.

16. Keskinen H, Kalliomäki P-L, Alanko K. Occupational asthma due to stainless steel welding fumes. Clin Allergy 10 (1980) 151-159.

17. Lambert PM, Reid DD. Smoking, air pollution and bronchitis in Britain. Lancet 1 (1970) 853-857.

18. Langård $\mathrm{S}$, Norseth $\mathrm{T}$. Chromium. In: Friberg $\mathrm{L}$, Nordberg GF, Vouk VB, ed. Handbook on the toxicology of metals. Elsevier/North-Holland Biomedical Press, Amsterdam 1979, pp 383-397.

19. Lautner GM, Carver JC, Konzen RB. Measurement of chromium VI and chromium III in stainless steel welding fumes with electron spectroscopy for chemical analysis and neutron activation analysis. Am Ind Hyg Assoc J 39 (1978) 651-660.

20. Mantel N, Haenszel W. Statistical aspects of the analy sis of data from retrospective studies of disease. J Natl Cancer Inst 22 (1959) 719-748.

21. Mueller RE, Keble DL, Plummer J, Walker SH. The prevalence of chronic bronchitis, chronic airway obstruction and respiratory symptoms in a Colorado city. Am Rev Respir Dis 103 (1971) 209-228.

22. Oxhöj H, Bake B, Wedel H, Wilhelmsen L. Effects of electric arc welding on ventilatory lung function. Arch Environ Health 34 (1979) 211-217.

23. Stern RM. Production and characterization of a reference standard welding fume. The Danish Welding Institute, Copenhagen 1979. $66 \mathrm{p}$.

24. Stern RM. Process-dependent risk of delayed health effects for welders. Environ Health Perspect 41 (1981) 235-253.

25. Thomsen E, Stern RM. A simple analytical technique for the determination of hexavalent chromium in welding fumes and other complex matrices. Scand J Work Environ Health 5 (1979) 386-403.

26. Ulfvarson U. Survey of air contaminants from welding. Scand J Work Environ Health 7 (1981): suppl $2,28 \mathrm{p}$

27. Ulfvarson U, Hallne U, Bellander T. Svetsning i rostfritt stål med metallbågsvetsning och gasbågsvetsning [Welding in stainless steel with metal arc-welding with covered electrodes and gas-shielded welding]. National Board of Occupational Safety and Health, Solna 1978. (Arbete och hälsa 1978: 8). (English abstract)

28. Vallyathan V, Bergeron WN, Robichaux PA, Craighead JE. Pulmonary fibrosis in an aluminum arc welder. Chest 81 (1982) 372-374.

29. Wilhelmsen L, Tibblin G. Tobacco smoking in fiftyyear-old men: Respiratory symptoms and ventilatory function tests. Scand J Respir Dis 47 (1966) 121-130.

30. World Health Organization. Early Detection of Chronic Lung Diseases: Report on a WHO meeting, Vienna 31 May - 2 June 1978. Copenhagen 1980. (WHO EURO reports and studies 24 ).

Received for publication: 30 July 1984 